\title{
Students' Performance and Perceptions Towards Authentic Learning Environment Based on Visual Thinking Continuum
}

\author{
https://doi.org/10.3991/ijet.v16i23.27455 \\ Noor Azean Atan $\left.{ }^{\bowtie}\right)$, Zaidatun Tasir, Mohd Fadzli Ali, Mohd Shafie Rosli, \\ Mohd Nihra Haruzuan Mohamad Said \\ Universiti Teknologi Malaysia, Johor, Malaysia \\ azeaneutm. my
}

\begin{abstract}
This paper explores the changes in student's level of achievement and perception towards authentic learning environment based on visual thinking elements. The three elements in visual thinking continuum are visual thinking, visual learning and visual communication. This research is a quantitative design involving quantitative and qualitative data. Research instruments included pre and post achievement tests, and a questionnaire on student's perception towards visualization level. There are 29 samples students, from teacher training first degree program in one of Malaysian public universities. The research data were analyzed by inferential and descriptive statistical analysis. Research findings through paired-sample t-test showed that there is a significant difference between scores of mean for the pre-test and post-test $(p<0.05)$ and shows positive student's perception towards authentic learning environment. All students have experienced positive growth in their level of visualization through authentic learning environment activities which based on visual thinking elements. Therefore, it can be concluded that the visual-based website has helped to enhance the students' performance and visualization levels.
\end{abstract}

Keywords - authentic learning environment, continuum visual thinking, visualbased website, visualization

\section{$1 \quad$ Introduction}

Several studies have looked at ways to improve as much as to address problems encountered by students in Information and Communication Technology (ICT) programmes [31,36]. Issues related to ICT are typically derived from stakeholder training as ICT is a constantly evolving field attributed to the advancement of technology and the need for new knowledge and skills. Therefore, ICT is a constant issue for instructors which equally require raw theoretical knowledge base and a set of practical cross-disciplinary skills. According to [4] and [24], students of a teaching programme are expected to be proficient in ICT i.e., to master computer handling, possess comprehensive knowledge on ICT, technically capable of utilizing ICT and aware of their roles in the teaching of ICT in their future teaching profession. 
The study was carried out in order to find the best practices and strategies for a teaching programme which will encourage both practical and theoretical understanding of ICT concepts for the purpose of teaching profession. As stated in [16,32], traditional teaching programmes encourage less skill development in students. Therefore, numbers of research have been carried out on ICT education and the enhancement of students' skills in technology and multimedia $[15,47,9]$.In order to ensure that teaching and learning (T\&L) in Computer Sciences remains effective, students of a teaching programme must have a firm foundation in terms of understanding and practical ICT skills [16,24]. This will encourage future teachers to teach, use and apply ICT within their T\&L classrooms after graduation.

Some research studies designed to address concerns regarding ICT teaching and learning must be the focal reference to increase the knowledge and skills of teachers. A study by [43] for instance concerned on the use of visual materials in computer networking and data communications. Another study conducted by [26] and [6] examined the use of animation in teaching Computer Sciences. Meanwhile, [25] conducted a study involving computer networking instruction through modelling. Another study by [42] used a simulator based on a graphical user interface (GUI) to teach data communications and telecommunications, allowing students to illustrate the content of learning while simultaneously experience an interface that is capable of resembling the real- life representation the learning process.

\section{$2 \quad$ Literature review}

Studies by $[8,48,30]$ which were carried out in several phases concluded that in teaching and learning of Computer Sciences subjects, there is a requirement for reallife representations which will go beyond conventional teaching methods and allow students to construct their own knowledge models through tutorial classes. For instance, utilization of visual media to represent a situation provides opportunities for the students of a teaching programme to simulate the real-life experience of learning thus enhancing their visual thinking [2,7]. Computer-based teaching approaches and strategies found in other research could also potentially help to increase students' thinking capability, knowledge and skills to apply and teach Computer Sciences subjects better $[25,24,33]$.

Studies by [2] found that utilization of visuals in teaching and learning is capable of increasing students' understanding and information retention. Other previous studies by $[12,43,48]$ demonstrated that visual learning systems allow students to learn clearly and that such systems increase students' achievement in terms of both knowledge and skills. However, the use of visual elements must be evaluated in a more systematic manner in order to design a truly meaningful learning environment. It is clear that the use of visual media is vital to provide an opportunity for students to learn the skills they will need in the real world.

However, a study by $[37,28]$ on the use of visual learning led to the development of a continuum of visual thinking, such that when students make use of and interact with the visual tools provided by a learning system, their visual thinking and learning skills 
increased profoundly from visual thinking to visual learning elements, and eventually to the highest element known as visual communication. Elements of visual thinking include use of pictures, colors, diagrams or other visual media as well as animation and simulation human utilize visual thinking to imagine or conceptualize problems, or rather visualize the reality within a certain boundary of limitation [3,28]. Meanwhile, elements of visual instruction derive from the development of visual thinking i.e. learning through visuals and interacting with them. Having learned to think in terms of visual images, students are able to communicate using visual elements. Visual communication element refers to creation or usage of a visual medium to explain or translate informational details without the use of words.

Besides the issue of students' visual thinking, there is often a divide between the aspects of knowledge and practical application both in schools and universities. Greater emphasis towards important principles, concepts and facts besides instructions that more focused towards abstract context in teaching and learning process is not sufficient to establish correlation between students' learning and real-life experiences. Subsequently, students are not able to access relevant information to solve similar problems found in the real job market i.e. realistic problems or better known as actual or authentic problems. As stated in $[1,38,46]$ truly authentic assignments require students to work cooperatively. Thus, utilization of the existing web-based communication tools such as emails, bulletin boards, blogs, online chatting and other commercial interactive tools found on the internet allow students to configure problems, discuss certain topics, and exchange information to solve real-world, authentic problems. Also, through these web-based communication tools, instructors are able to communicate better with advice or guidance or respond to students either individually or as groups which are the crucial elements in producing authentic learning. Therefore, web-based learning is ideal in implementing an authentic learning environment on the foundation of situation-centered learning characteristics and elements of authentic tasks.

Consequently, this study developed a learning website which integrated visual applications in an authentic learning environment as proposed in [34,17] through stages of learning activities for one of the subjects in Computer Sciences, i.e., Telecommunications and Computer Networking. The use of visuals from a computer logic perspective applied in this learning website is based on a proposal by [30]. According to [37,28] the continuous provision of visual materials for learning will promote students' better understanding of concepts. In addition, it helps to stimulate students' continuum development that improves from visual thinking to visual learning, and eventually to the highest-level i.e. visual communication which is the foundation of the social process of learning [28].

Findings from the observation and assessment of this learning activity allowed researchers to determine whether it is capable of supporting students 'increase in performance. The perception of students regarding web-based learning in an authentic visualised environment was obtained accordingly. 
Paper-Students' Performance and Perceptions Towards Authentic Learning Environment Based on...

\section{$3 \quad$ Research objectives}

This study covered two interrelated objectives as follow:

1. Development of a visualised website that was designed based on an authentic learning environment and visual thinking continuum elements.

2. Assessment of the visualised website's effectiveness from the following aspects:

(a) Students' level of performance in terms of knowledge-based content.

(b) Students' perceptions towards the usage, integration and visual application in the process of teaching and learning.

\section{Theoretical framework}

This study emulated Situated-Based Learning Theory. Consequently, a study had been conducted by $[39,17]$ with regards to the effectiveness of situated-based learning with assessments and authentic tasks, and benefits derived from the usage of the multimedia elements were identified. Studies have also been carried out by $[23,34,18]$ which refer to the characteristics of situated-based learning together with the criteria of authentic tasks and the capacity of web technology renown as authentic learning environment. Based on the authentic learning environment as well as the wide-ranging access to internet facilities $[41,17]$ in research among students of higher education institutions. With reference to the research findings obtained, therefore this study has adapted the characteristics outlined by [17] through learning in the authentic environment while incorporating the criteria of situated-based learning as well as authentic tasks via the utilization of multimedia elements over the web.

The situated-based and authentic learning characteristics were integrated in a website through learning activities which were carried out in stages along with visual media utilization that is capable of supporting students' visual thinking as proposed by [28] to establish visual thinking continuum, i.e. the upstaging from visual thinking to visual learning that ultimately led to visual communication. The following are characteristics of situated- based learning applied in the design of the visualised website in this research as elaborated by [41,29] and also in [21], as well as the joint research by [17] which focused more on teaching and learning in authentic environments among students of higher education institutions:

- Producing an authentic context which is capable of conceptualizing how knowledge shall be applied in real life

- Producing authentic activities

- Developing access to proper implementation and the proses of modelling a real-life concept

- Encouraging a variety of roles and perspectives

- Supporting collaborative knowledge

- Encouraging reflection

- Encouraging articulation

- Providing coaching and scaffolding

- Producing authentic learning assessment which includes assignments 
To construct an authentic learning environment, the implementation of authentic learning characteristics is also required to compliment the development of a learning system that has been developed, and each of the characteristic is adapted from the research of $[41,10,18]$ :

- Authentic assignments should be relevant to the real world

- Authentic assignments are open, requiring students to identify subtasks that are needed to accomplish the activity

- Authentic assignments consist of complex assignments to be studied by students in a longer term

- Authentic assignments allow students to identify and study the tasks in various perspectives as well as utilizing various resources

- Authentic assignments provide opportunities to collaborate

- Authentic assignments give chances for reflection

- Authentic assignments can be integrated and applied across disciplines of subjects and reach out further than specified

- Authentic assignments are comprehensively integrated with assessments

- Authentic assignments are capable of yielding products that are more valuable and meaningful in their own ways, better than a product specifically designed to address a purpose

- Authentic assignments allow solutions that are capable to compete with variations of outcomes

Next is a brief description of visual application features to be integrated with the web-based authentic learning environment as recommended by [30] in their study with regards to one of the Computer Sciences subjects that provides support for students to think visually in their learning process:

- Provides variation of resources and other references to help students interpret image representations

- Provides visuals that match students' knowledge

- Provides views from multiple angles

- Provides a flexible user control panel

- Provides a chance for students to develop visual materials themselves

- Provides students a chance to provide data input to the visual representation

- Provides dynamic interaction space for students

- Provides dynamic or automatic feedback to students

- Provides explanations along with the provided visual representations

Every characteristic of the use of visuals had been integrated with the design of the visualised website that was developed within the authentic learning environment to increase levels of visualization and comprehension among students in the teaching and learning of Telecommunications and Computer Networks. It also supported the development of visual thinking for learning Computer Networking and Communication. The use of visuals in T\&L is not only functioning as a pedagogical or heuristic tool but may also serve to promote thinking and motivation in learning. As there is a wide variety of 
media available for visual representation via contemporary technology, this provides visual experience for learners and improves their understanding to the higher level [40,28]. Figure Error! Reference source not found. depicts the sequence of visual representation for students in a particular instructional system being developed.

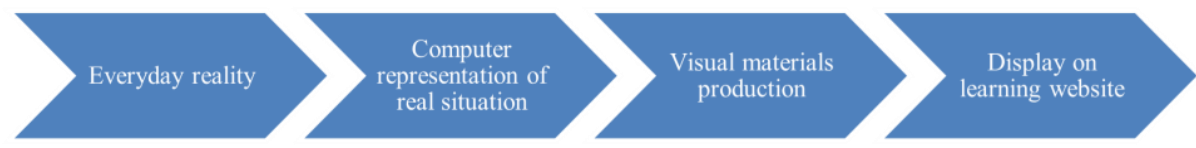

Fig. 1. Visual Representation Sequence

All of the previous characteristics of the use of visuals had been integrated in parallel with the element of visual thinking continuum. The gestalt theory and visual psychology was developed further by [5] in terms of visual thinking [40,5] on learning, thinking, and visual communication and further improved and elaborated by [28] as:

- Visual thinking

- Visual learning

- Visual communication

According to $[22,28]$ visual ranking generally begins with the stage of using visual materials. This is followed by the manipulation i.e. constructing knowledge through visual interaction towards the visual representation up to the stage of sharing and communication to present and highlight ideas through visual and verbal utilizations with other students. Learning improves by providing students with tools and activities to develop meaningful relationships between different concepts as well as allowing them to explore the concepts verbally and visually. Therefore, visual thinking thus can spur visual communication, which is fundamental to long term learning improvements. Figure 2 depicts the visual thinking continuum produced in the research of which concerns on how a student's level of visual communication increases from visual thinking to visual utilization up to the ultimate stage which is the capability to communicate using visuals in the visualised website being developed.
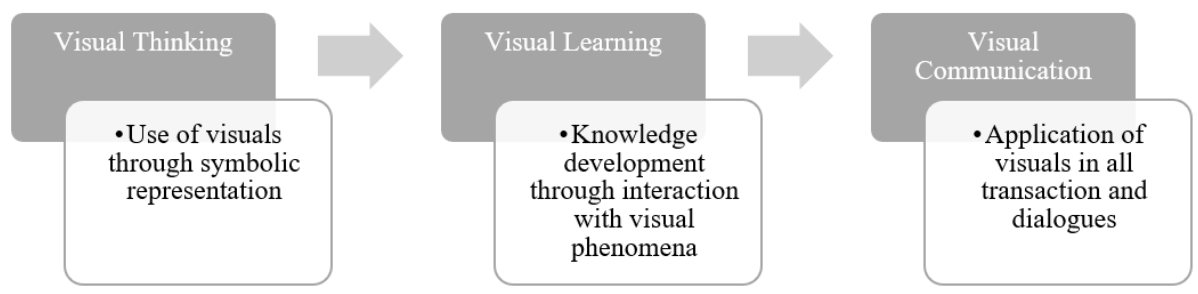

Fig. 2. Visual Thinking Continuum

Each stated feature had been used as a guide to design a visualised website being developed. Integration of all features of authentic together with the characteristics of the usage of visual representation in parallel with the visual thinking continuum was 
Paper-Students' Performance and Perceptions Towards Authentic Learning Environment Based on...

aimed at increasing levels of visualization and understanding towards the ICT usage and application in their teaching and learning process.

\section{$5 \quad$ Methodology}

\subsection{Sampling and population}

The sample for this study came from the Faculty of Education at a local Malaysian Higher Education Institution from the SPP Programme (Physics), SPK Programme (Chemistry) and SPT Programme (Mathematics) which participated in Telecommunications and Computer Networking course. The sample which comprised of future teachers involved in the development of the study. According to information provided by management, 29 students working on a Bachelor of Science and Computer Education were randomly sampled. However, there were some dropouts during the study between the pre-test and post-test, so the total number reduced to 22. According to [11] dropouts are a serious threat to a study and when they occur, the said sample should be dropped. In terms of the gathering of sample data for the visual thinking continuum, there were 29 people in the sample. The students used the prepared visual website for six weeks for the teaching and learning of the Telecommunications and Computer Networking subject. Students took pre and post-tests and also a content-based questionnaire to measure their perception of their own level of visualization both before and after using the visual website. The pre and post-tests assessments of the visual thinking continuum were carried out per the single-group time series design. Twelve students also volunteered for an interview.

\section{$6 \quad$ Result}

\subsection{Analysis of pre and post-tests based on content}

Table 1 compares the results of students, both pre-test and post-test, for the teaching and learning of the Telecommunications and Computer Networking subject. The table depicts actual scores, percentages, grades, and differences between scores on the pre and post-tests.

As per Table 1, a total of 22 students took both the content-based pre and post-tests. The highest score was 32.5, for a percentage of $57 \%$. The lowest score on the pre-test was 22 , for a percentage of $39 \%$. For the post-test, the highest score was 21 points (89\%) while the lowest score was 32.5 points $(57 \%)$. In general, students showed an increase in their levels of performance between the pre and post-tests. The maximum score difference for the increase was 20.5 points, while the minimum increase was 9 points. 
Table 1. Comparison of Student's Performance

\begin{tabular}{|l|c|c|c|c|c|c|}
\hline $\begin{array}{c}\text { Students } \\
\text { ID }\end{array}$ & $\begin{array}{c}\text { Total Score } \\
\text { Pre-Test }\end{array}$ & $\begin{array}{c}\text { Total Score } \\
\text { Post Test }\end{array}$ & $\begin{array}{c}\text { Pre-Test } \\
\mathbf{( \% )}\end{array}$ & $\begin{array}{c}\text { Post Test } \\
\text { (\%) }\end{array}$ & Difference & Performance \\
\hline P01 & 27.0 & 39.5 & 47 & 69 & 12.5 & $\uparrow$ \\
\hline P02 & 27.5 & 46.0 & 48 & 81 & 18.5 & $\uparrow$ \\
\hline P03 & 29.0 & 43.0 & 51 & 75 & 14.0 & $\uparrow$ \\
\hline P04 & 31.5 & 43.5 & 55 & 76 & 12.0 & $\uparrow$ \\
\hline P05 & 26.5 & 35.5 & 46 & 62 & 9.0 & $\uparrow$ \\
\hline P06 & 29.5 & 48.5 & 52 & 85 & 19.0 & $\uparrow$ \\
\hline P07 & 24.0 & 37.0 & 42 & 65 & 13.0 & $\uparrow$ \\
\hline P08 & 31.5 & 49.5 & 55 & 87 & 18.0 & $\uparrow$ \\
\hline P09 & 31.5 & 51.0 & 55 & 89 & 19.5 & $\uparrow$ \\
\hline P10 & 32.5 & 43.0 & 57 & 75 & 10.5 & $\uparrow$ \\
\hline P11 & 23.5 & 35.0 & 41 & 61 & 11.5 & $\uparrow$ \\
\hline P12 & 25.0 & 35.0 & 44 & 61 & 10.0 & $\uparrow$ \\
\hline P13 & 26.5 & 43.0 & 46 & 75 & 16.5 & $\uparrow$ \\
\hline P14 & 28.5 & 44.5 & 50 & 78 & 16.0 & $\uparrow$ \\
\hline P15 & 26.0 & 37.0 & 46 & 65 & 11.0 & $\uparrow$ \\
\hline P16 & 26.5 & 38.5 & 46 & 68 & 12.0 & $\uparrow$ \\
\hline P17 & 23.5 & 32.5 & 41 & 57 & 9.0 & $\uparrow$ \\
\hline P18 & 28.0 & 37.5 & 49 & 66 & 9.5 & $\uparrow$ \\
\hline P19 & 30.5 & 42.5 & 54 & 75 & 12.0 & $\uparrow$ \\
\hline P20 & 22.0 & 42.5 & 39 & 75 & 20.5 & $\uparrow$ \\
\hline P21 & 28.5 & 41.0 & 50 & 72 & 12.5 & $\uparrow$ \\
\hline P22 & 27.5 & 39.0 & 48 & 68 & 11.5 & $\uparrow$ \\
\hline
\end{tabular}

* N $=22,=\uparrow$ Increase, $\leftrightarrow=$ Same, $\downarrow=$ Different

Figure 3 clearly depicts a comparison of pre and post-tests grades. The range of grades for students taking the pre-test was $\mathrm{C}+$ to $\mathrm{E}$, where $\mathrm{E}$ is considered to be the lowest grade for the Telecommunications and Computer Networking course. For the pre-test, only five students obtained the relatively highest grade of $\mathrm{C}+$, while a majority of eight students obtained a $\mathrm{C}$ and 4 obtained a $\mathrm{D}+$, which was very close to a failing grade. Results indicated Figure 3 show that a large contingent of students earned a grade of A to B-. If "A" is considered excellent than nine students may be classified as excellent. A group of 12 students received a $\mathrm{B}+$ to $\mathrm{B}$ - while one student received a relatively low grade of $\mathrm{C}+$. The results of data analysis for the pre and post-tests and statistical analysis include a paired-sample t-test, which is a parametric test for normally-distributed data. Table 2 show the outcomes of the analysis. 


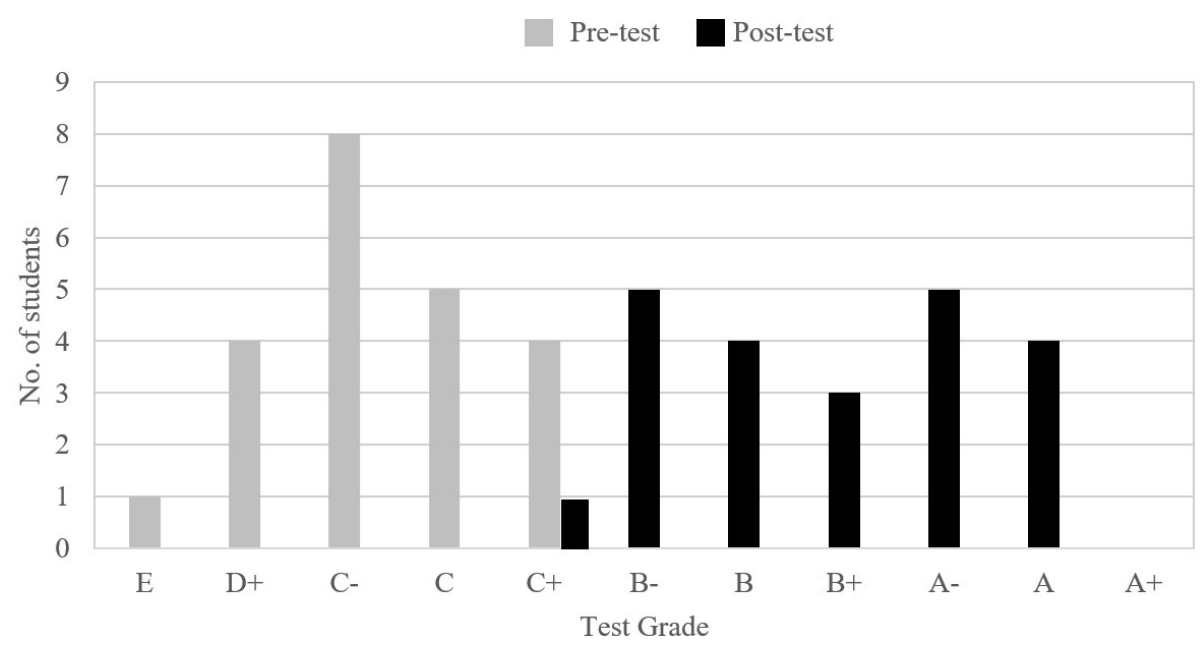

Fig. 3. Summary Grades for Pre-Test and Post Test

Table 2. Comparison of Students` Performance

\begin{tabular}{|l|c|c|c|c|c|}
\hline & Min & Standard Deviation & t & Sig.(2-tailed) & Cohen d (power) \\
\hline Pre-Test & 25.57 & 2.90 & -17.495 & 0.000 & $4.28(0.84)$ \\
\hline Post-test & 41.11 & 4.97 & & & \\
\hline Pre-Test $\sim$ Post-Test & & & & & \\
\hline
\end{tabular}

Table 2 elucidates that the mean scores for pre and post-tests differed remarkably, with scores between 27.57 and 41.11. The table also shows that the significance of the pre and post-tests mean scores at $\mathrm{p}=0.00$ is lower than the significance level of 0.05 . Therefore, it has been concluded that using visual websites between the pre and posttests had an impact on performance with a large effect $(\mathrm{d}=4.28)$ and high power $(0.84)$. Analysis using GPower software found that the value of 0.84 would require four people, so the sample size of 22 was considered adequate.

\subsection{Analysis of questionnaire data regarding students' perceptions on visualization}

This section contains data about students' perceptions on visualization and had been divided into three elements. Table 3 compares the overall mean for each student according to the visual elements in continuum which have been described.

Based on Table 3, the mean for each continuum before use of the website approached a value of 3.00. The lowest mean of 2.95 represents application of visual communication for students. However, a value more than 3.50 for student perceptions was reached after the use of the website. The greatest mean value was for the use of visual thinking after use of the website. Table 3 also describes other means for student perception of the learning system provided for Telecommunications and Computer Networking and 
shows a relatively high mean value of 4.05 . Students tended to have a positive perception of such a learning system, which helps encourages students to better learn computer subjects through high-level visualization. To determine the existence of a significant difference in students' perceptions on the impact of a visual website in terms of the three elements of the above continuum, t-test procedures and an ANOVA test had been carried out. More statistical analysis is shown in Table 4.

Table 3. Differences in Both Overall Mean and Standard Deviation for the Continuum and Views of Students about the Learning System

\begin{tabular}{|l|l|c|c|c|c|}
\hline \multirow{2}{*}{ No Details } & \multicolumn{2}{c|}{ Before Use of Website } & \multicolumn{2}{c|}{ After Use of Website } \\
\cline { 3 - 6 } & & Mean & SD & Mean & SD \\
\hline 1 & Use of visual in students' thinking & 3.32 & 0.56 & 3.95 & 0.43 \\
\hline 2 & Integration of visual learning & 3.33 & 0.42 & 3.90 & 0.34 \\
\hline 3 & Application of visual communication & 2.95 & 0.50 & 3.51 & 0.40 \\
\hline 4 & System of studying through the visual web & & & 4.05 & 0.46 \\
\hline
\end{tabular}

Table 4. Comparison of Mauchly“ Test Range Through Bilateral Anova Test for the Questionnaire on Students' Visualization Level.

\begin{tabular}{|l|c|c|c|c|c|c|c|}
\hline \multicolumn{7}{|c|}{ Mauchly's Test of Sphericity (b) } \\
\hline $\begin{array}{c}\text { Within Subjects } \\
\text { Effect }\end{array}$ & $\begin{array}{c}\text { Mauchly's } \\
\boldsymbol{W}\end{array}$ & $\begin{array}{c}\text { Approx } \\
\text { Chi Square }\end{array}$ & $\boldsymbol{D f}$ & Sig. & $\begin{array}{c}\text { Greenhouse } \\
\text { Geisser }\end{array}$ & $\begin{array}{c}\text { Huynh- } \\
\text { Feldt }\end{array}$ & $\begin{array}{c}\text { Lower } \\
\text { Bound }\end{array}$ \\
\hline Continuum & 0.84 & 3.45 & 2 & 0.18 & 0.86 & 0.93 & 0.50 \\
\hline before-after & 1.00 & 0.00 & 0 & $*$ & 1.00 & 1.00 & 1.00 \\
\hline * before-after & 0.79 & 4.80 & 2 & 0.09 & 0.82 & 0.89 & 0.50 \\
\hline
\end{tabular}

The results on the 3x2 factorial analysis of Mauchly's Test of Sphericity in Table 4 explains that students' perceptions of the continuum show results that are not significant $(p=0.18)$ at $p>0.05$. Based on this, it may be assumed that the range does not fulfil conditions (an assumption of sphericity had not been violated which sphericity is assumed). Next, it may be seen in Table 5 that students' perceptions on visual websites in the three levels of the continuum shows significant differences in the $\mathrm{F}$ value of (df $=2,42, \& \mathrm{p}<0.05)$. Due to this difference, it may be concluded that the use of visual websites by students in learning Telecommunications and Computer Networking had an influence on their perception of each level of the continuum. This is also seen in the test results of Mauchly's Test of Sphericity of student perceptions before and after the use of the website, as the results are not significant at $p>0.05$ (refer to Table 6). Therefore, it may be concluded that the assumption of sphericity had not been violated, as sphericity is assumed.

Accordingly, analysis in Table 5 indicates no significant difference in the interaction between perceptions of students at each level of the continuum before and after the use of the website, with the $\mathrm{F}$ value of $(\mathrm{df}=2,42 \& \mathrm{p}>0.05)$. This further indicates that students' perceptions at each level are either not dependent upon or not determined by 
Paper - Students' Performance and Perceptions Towards Authentic Learning Environment Based on..

the perception of the students before use of the visual website for Telecommunications and Computer Networking.

Table 5. Tests of Within- Subjects Effects through an ANOVA test for the level of students، visualization

\begin{tabular}{|l|c|c|c|c|c|c|}
\hline \multicolumn{1}{|c|}{ Source } & Type III Sum of Squares & Df & $\begin{array}{c}\text { Mean } \\
\text { Square }\end{array}$ & F & Sig. & $\begin{array}{c}\text { Partial Eta } \\
\text { Squared }\end{array}$ \\
\hline \multicolumn{7}{|c|}{ Continuum } \\
\hline Sphericity Assumed & 4.62 & 2.00 & 2.31 & 25.5 & 0.00 & 0.55 \\
\hline Huynh-Feldt & 4.62 & 1.87 & 2.48 & 25.53 & 0.00 & 0.55 \\
\hline \multicolumn{7}{|c|}{ Error Continuum } \\
\hline Sphericity Assumed & 3.80 & 42.0 & 0.09 & & & \\
\hline $\begin{array}{l}\text { Huynh-Feldt before-af- } \\
\text { ter }\end{array}$ & 3.80 & 39.2 & 0.10 & & & \\
\hline Sphericity Assumed & 11.45 & 1.00 & 11.45 & 34.58 & 0.00 & 0.62 \\
\hline Huynh-Feldt & 11.45 & 1.00 & 11.45 & 34.58 & 0.00 & 0.62 \\
\hline \multicolumn{7}{|c|}{ Error (before-after) } \\
\hline Sphericity Assumed & 6.95 & 21.00 & 0.33 & & \\
\hline Huynh-Feldt & 6.95 & 21.00 & 0.33 & & \\
\hline \multicolumn{7}{|c|}{ Continuum *before-after } \\
\hline Sphericity Assumed & 0.04 & 2.00 & 0.02 & 0.17 & 0.85 & 0.01 \\
\hline Huynh-Feldt & 0.04 & 1.78 & 0.02 & 0.17 & 0.82 & 0.01 \\
\hline \multicolumn{7}{|c|}{ Error (Continuum *before-after) } \\
\hline Sphericity Assumed & 4.64 & 42.00 & 0.11 & & \\
\hline Huynh-Feldt & 4.64 & 37.18 & 0.13 & & \\
\hline
\end{tabular}

Table 6. Post-hoc test of students' perceptions using Bonferroni correction

\begin{tabular}{|c|c|c|c|c|c|c|}
\hline \multicolumn{2}{|c|}{ Pairwise Comparisons } \\
\hline $\begin{array}{c}\text { (I) before-af- } \\
\text { ter }\end{array}$ & $\begin{array}{c}\text { (J) before- } \\
\text { after }\end{array}$ & $\begin{array}{c}\text { Mean Dif- } \\
\text { ference (I-J) }\end{array}$ & Std.Error & Sig.a & \multicolumn{2}{|c|}{$\begin{array}{c}\text { \%5\% Confidence Interval } \\
\text { for Difference (a) }\end{array}$} \\
\cline { 4 - 7 } & & -0.59 & 0.10 & 0.00 & -0.80 & $\begin{array}{c}\text { Upper } \\
\text { Bound }\end{array}$ \\
\hline 1 & 2 & 0.59 & 0.10 & 0.00 & 0.38 & $0.80 \mathrm{a}$ \\
\hline
\end{tabular}

Adjustment for multiple comparisons: Bonferroni.

Table 7 shows the means for students' perceptions based on a questionnaire about the three-level continuum. The table shows that 18 to 19 students reported improvements, while only 2 to 3 students indicated a decrease or remained the same in their perceptions. 
Paper-Students' Performance and Perceptions Towards Authentic Learning Environment Based on...

Table 7. Summary Comparisons on Students' Perceptions Based on the Questionnaire Concerning the Three-Level Continuum

\begin{tabular}{|l|c|c|c|}
\hline $\begin{array}{c}\text { Changes in student } \\
\text { perception before and after use of visual website }\end{array}$ & $\begin{array}{c}\text { Use of visual } \\
\text { thinking }\end{array}$ & $\begin{array}{c}\text { Integration of vis- } \\
\text { uals into learning }\end{array}$ & $\begin{array}{c}\text { Use of visuals in } \\
\text { communication }\end{array}$ \\
\hline Increased & 18 & 18 & 19 \\
\hline Same & 2 & 2 & 0 \\
\hline Decreased & 2 & 2 & 3 \\
\hline
\end{tabular}

\subsection{Interviews regarding visualised website effectiveness}

Group interviews were carried out to get the opinions of students in the Telecommunications and Computer Networking course. Interviews were focused on the first two questions, in terms of the effectiveness of visual websites on student learning and impacts on student visualization levels. Figures 4 and 5 provide a summary of coding themes for students' interviews. Five interview questions have focused on the effectiveness of visual websites on teaching and learning, while three other questions concerned the effectiveness of visualised websites in terms of visualization level. Based on the themes' coding in Fig. 4 and 5, students responded positively in interviews regarding the effectiveness of visual websites on teaching and learning. Some questions were asked to elicit views from students.

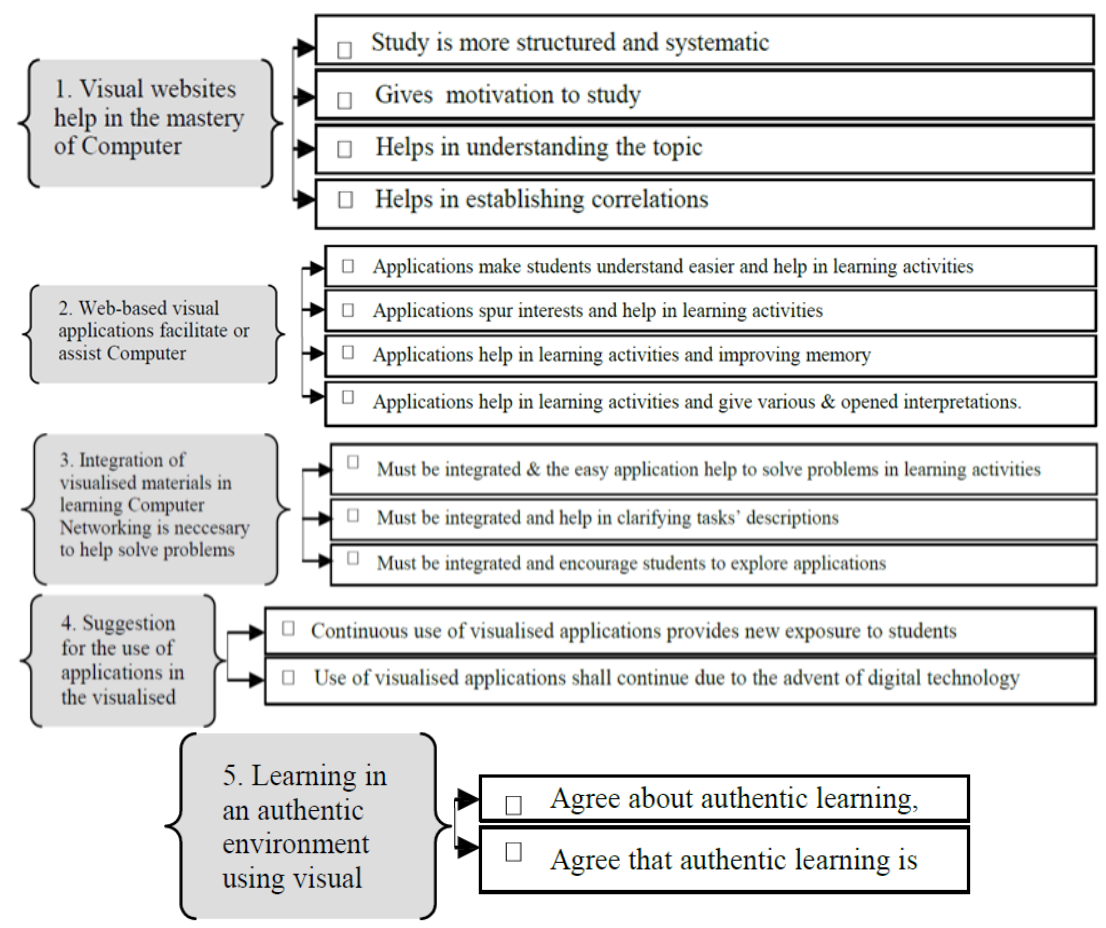

Fig. 4. Summary of themes' coding on effectiveness of visual websites for students' T\&L 


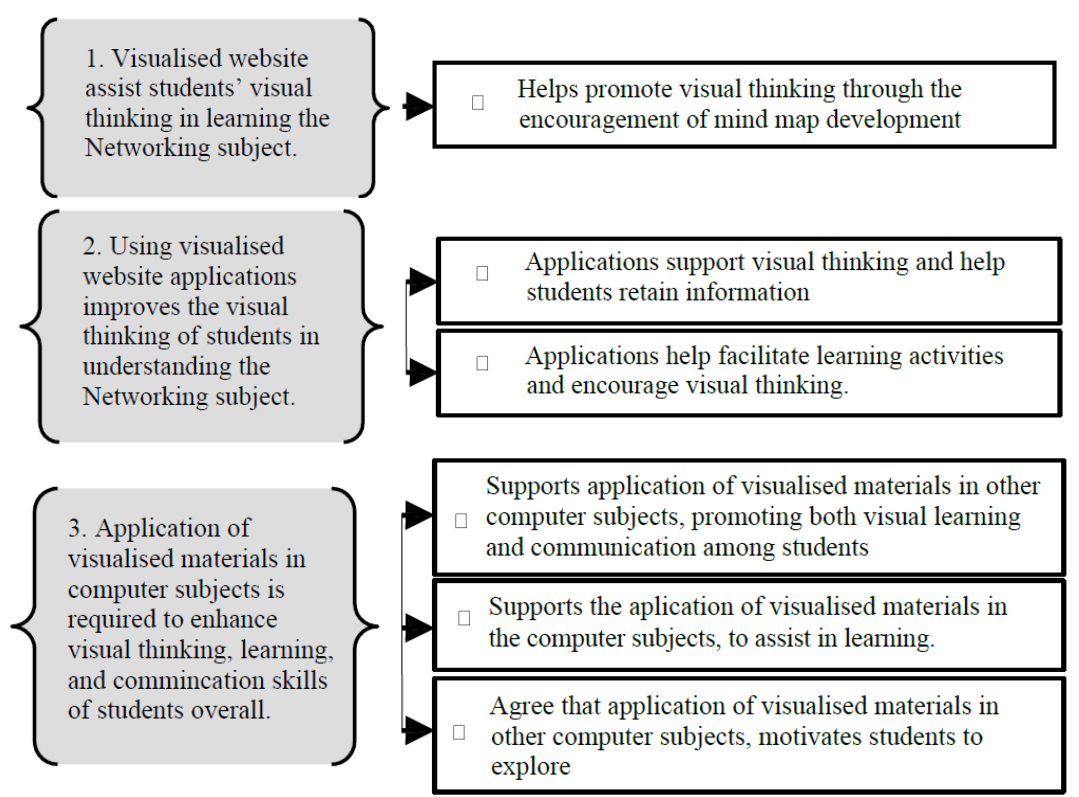

Fig. 5. Summary of themes' coding on effectiveness of visualised websites towards students' visualization level.

\section{Discussion}

\subsection{Summary and discussion on the impacts of visualised website towards students' performance on tests}

Based on the pre and post-tests results for the 22 students, only one student failed the pre-test at $39 \%$, which is a barely the failing mark for the Telecommunications and Computer Networking subject. However, other students were able to pass with an average grade of $50 \%$, with the lowest being $41 \%$ and the highest being $57 \%$.

In this study, all students improved by at least 9 points or $15 \%$ between the pre and post-tests. Most students earned a B or A-. Results also showed that the post-test grades were far higher than the pre-test grades overall, as the pre-test had a low average of $\mathrm{C}+$ or below, with most students receiving a C-. These results are in line with research conducted by [28] which reported that students need time and space to use visual materials to gradually come to greater understanding.

This increase could be due to the fact that students are allowed to use visual websites throughout the learning process, having a positive impact on students' achievement. To determine whether the difference between the two tests was significant, a pared sample t-test was employed. Based on these results, there were significant differences in pre and post-tests scores at $(\mathrm{p}=0.00)$, at $\alpha=0.05$ significance level. To be clear, the mean of pre and post-tests scores showed a difference, with an improvement in teaching and 
learning for Telecommunication and Computer Networking. Improved student achievement has been associated with learning in an 'authentic' web-based learning environment. This adds enjoyment to learning and allows students to experience real-world problems. Some examples of student responses are as follow:

P5: Of course real experience is important, we can see issues more clearly, and better understand the flow of things.

P2: the experience was quite enjoyable because we went to Johor Education Department, and when we went there, we felt proud about the results. We really got something.

This study's findings are similar to those found by [27,13]. Their studies also described the use of computer-based visuals for instruction and found a positive impact on students in terms of their teaching and learning activities. Other than that, the study findings also demonstrate that during the post-test, students are able to give not only the normal answers, but also rational reasoning with relevant visualizations to support their answer. The final questions in the pre- and post-tests demanded that students think about the answer and use reasoning, not just memorization yet more towards authentic problem solving in the context of the real world. Students were able to correlate the topic they learned with other topics and real situations. This has also been supported by interviews conducted for the study in which students stated their preference for visual websites. The following statements indicate their sentiment:

P10: It helps in problem-solving because we can relate the visuals directly with other visuals.

P4: being able to link like this has made learning more interesting for me, what I learned last week, I am able to add on to this week.

Effective visual websites do not just have an impact on students' performance, but also have an effect on the development of students' visualization, as indicated in the discussion of the following section.

\subsection{Summary and discussion on student perception of visualization, before and after}

Visual website usage. Based on students' perceptions on visualization for the three continuums, they had a generally positive response, with a minimum mark of 3.18 and a maximum mark of 4.41 for the integration of visuals in instruction after trying the visualised web site. These means scores indicate that students tend to support the use of such materials in teaching and learning. Students were excited about using these tools, as indicated by the following statements:

P5: this visual learning should continue. We really should continue because if we don't, it would be like the end of an era.

P8: In my opinion, this is absolutely required. At first, I didn't really like this subject because I didn't know anything about it, but after this class activity, I really enjoy using it.

The item regarding students' perception on the application of visual communication appeared to have done well in terms of mean score, although it started out low. Scores before using the site started out as low as 2.86 , but rose to 3.68 , an increase of 0.82 . This item indicates that students tend to use visual objects when studying computer- 
Paper-Students' Performance and Perceptions Towards Authentic Learning Environment Based on...

related subjects. According to studies conducted by [45] if students have a good impression of visual learning materials that are capable of improving their visual thinking, this is a positive demonstration of their visual levels. Also, [43] stated that such a situation illustrates students 'interests to keep on learning and marks the increase in their understanding. In a similar way, students' opinion on the visual learning system was high, with mean scores averaging more than 4.0. Visual learning on such websites was shown to increase students' visual thinking and encourage them to use visual objects in their learning activities, as students become more comfortable with features such as forums and online.

\section{Conclusion}

According to the study findings, all respondents who followed the process of teaching and learning in Telecommunications and Computer Networking reported an increase in achievement levels between pre and post-tests. Most students showed a great deal of improvement while some showed moderate or lower levels of improvement. The effectiveness of the 'visual web' is not only seen in terms of impact on student achievement, but also positive changes in terms of students' visual thinking, visual learning and their visual communication.

\section{Acknowledgement}

We would like to acknowledge Universiti Teknologi Malaysia (UTM) for sponsoring our work in UTM Encouragement Research vot number Q.J130000.3853.18J82 and Research Management Centre, Universiti Teknologi Malaysia for managing our grant.

\section{Reference}

[1] Albert, A. A., Ernest, K. K. \& Hlaviso, M. (2018). Authentic Learning: Enhancing Learners' Academic Literacy Skills. International Journal of Applied Linguistics \& English Literature, Vol. 7, No. 4.

[2] Almudena, F. F., Kay L. O., Sabine, T. \& Peter, W. (2019). A Multimodal Approach to Visual Thinking: The Scientific Sketchnote. Visual Communication Journal, SAGE Publications, Vol. 18, Issue 1, pp. 5-29.

[3] Alain, G. (2019). Visual Thinking Routines: Classroom Snapshots. Athens Journal of Education, Vol. 6, Issue 1, pp. 53-76.

[4] Ang S. R. \& Sandaran, S. C. (2020). Teachers' Practices and Perceptions of the Use of ICT in ELT Classrooms in the Pre-Covid 19 Pandemic Era and Suggestions for the 'New Normal'. LSP International Journal, Vol. 7, Issue 1, 2020, PP. 99-119. https://doi.org/10. $11113 /$ sspi.v7n1.100

[5] Arnheim, R. (1969). Visual Thinking. London, England: University of California Press.

[6] Balci, O., et al. (2001). Animations to Assist Learning Some Key Computer Science Topics. ACM Journal on Educational Resources in Computing (JERIC), Vol. 1, No. 2 (Summer). 
Paper-Students' Performance and Perceptions Towards Authentic Learning Environment Based on...

[7] Baldwin, L. P.\& Kuljis, J. (2000). Visualisation Techniques for Learning and Teaching Programming. Journal of Computing and Information Technology, Vol. 8, No. 4, pp. 285-291. https://doi.org/10.2498/cit.2000.04.03

[8] Barno, A., Khushruya, J. \& Azamat, K. (2020). Methods Of Teaching Computer Science in Higher Education. International Journal of Advanced Science and Technology, Vol. 29, Issue 7, pp. $2221-2224$.

[9] Byrum, D.\& Cashman, C. (1993). Preservice teacher training in educational computing: Problems, perceptions, and preparation. Journal of Technology and Teacher Education, 1(3), pp. 259-274.

[10] Chan T. K. (2020). Implementation and impact of authentic learning in a postgraduate applied physics course. Asian Journal of the Scholarship of Teaching and Learning, 10(2), pp. 153-170.

[11] Creswell, J. W. (2008). Educational Research: Planning, Conducting, and Evaluating Quantitative and Qualitative Research, 3rd Edition. Upper Saddle River, New Jersey: Pearson Education Inc. Davis, C. N., et al. (1998). Teaching Computer Networks through Modeling. Ada Letters, Vol. XVII, No. 5, pp. 104-110.

[12] Dina, N. Z., Wuryanto, E., \& Marjianto, R. S. (2019). Evaluation on the Effectiveness of Visual Learning Environment on Programming Course from Students' Perspectives. IIUM Engineering Journal, 20(1), pp. 100-107. https://doi.org/10.31436/iiumej.v20i1.993

[13] Fleischer, R. \& Trippen, G. (2007). On the Effectiveness of Visualizations in a Theory of Computing Course. In R. Lu, et al. (Eds.), In Cognitive Systems (pp. 15-24): Springer LNAI 4429. https://doi.org/10.1007/978-3-540-70934-3 2

[14] Griffen, R. E., et al. (2001). Exploring the visual future: art design, science and technology. The International Visual Literacy Association, pp. 129-134.

[15] Hafifah, G. N. (2020). Teachers Perspective of ICT Integration in English Language: A Review of Literature. Journal English Educators Society, 5(1), pp. 9-15. https://doi.org/ $10.21070 /$ jees.v5i1.205

[16] Hasan, O. (2021). Improving Teachers' Qualifications for Preparing ICT Based Educational Materials. Malaysian Online Journal of Educational Technology, Vol. 9, Issue 1. https://doi.org/10.17220/mojet.2021.9.1.245

[17] Herrington, J. \& Herrington, A. (2006). Authentic conditions for authentic assessment: Aligning task and assessment, in Critical Visions. Proceedings of the 29th HERDSA Annual Conference, Western Australia, pp. 146-151.

[18] Herrington, J. \& Knibb, K. (1999). Multimedia and student activity: An interpretive study using VideoSearch. Australian Journal of Educational Technology, 15(1), pp. 47-57. https://doi.org/10.14742/ajet.1846

[19] Herrington, J. \& Oliver, R. (1999). Using situated learning and multimedia to investigate higher-order thinking. Journal of Interactive Learning Research, 10(1), pp. 3-24.

[20] Herrington, J. \& Oliver, R. (2000). An instructional design framework for authentic learning environments. Educational Technology Research and Development, Vol 48, No.3, pp. 2348. https://doi.org/10.1007/bf02319856

[21] Herrington, J., et al. (2004). Designing authentic activities in web-based courses. Journal of Computing in Higher Education, Vol. 16 (1) pp. 3-29.

[22] Keith, S., Lisa A. Strycker, Lynne, A., Peggy, M. \& Lisa, A-S. (2020). The Visual Thinking Strategies Approach to Teaching Argument Writing A Professional Development Model. The Elementary School Journal, Vol. 121, No. 1.

[23] Lowell, V. \& Moore, R. (2020). Developing Practical Knowledge and Skills of Online Instructional Design Students Through Authentic Learning and Real-World Activities. 
Paper-Students' Performance and Perceptions Towards Authentic Learning Environment Based on...

Techtrends: Linking Research and Practice to Improve Learning, Vol. 64, No. 4, pp. 581590. https://doi.org/10.1007/s11528-020-00518-z

[24] Markauskaite, L., et al. (2006). Modelling and Evaluating ICT Courses for Pre-service Teachers: What Works and How It Works? In Informatics Education - The Bridge between Using and Understanding Computers (Vol. Vol. 4226/2006, pp. 242-254): Springer Berlin / Heidelberg. https://doi.org/10.1007/11915355_23

[25] Marina, P. \& Julije, O. (2020). Methods in Teaching Computer Networks: A Literature Review. ACM Transactions on Computing Education, Vol. 20 Issue 3, pp. 1-35.

[26] Medeiros, R. P., Ramalho, G. L., and Falcão, T. P. (2018). A Systematic Literature Review On Teaching And Learning Introductory Programming In Higher Education. IEEE Transactions on Education. https://doi.org/10.1109/te.2018.2864133

[27] McKim, R. H. (1980). Experiences in Visual Thinking (Second Edition). Monterey, California: Brooks/Cole Publishing Company.

[28] McLoughlin \& Krakowski, K. (2001). Technological tools for visual thinking: What does the research tell us? AUC Academic \& Developers Conference 2001.

[29] Melike, Ö. \& Fatma, Ö. (2017). The Effect of Situated Learning on Students' Vocational English Learning. Universal Journal of Educational Research, 5(11), pp. 2037-2044.

[30] Naps, T. L., et al. (2003). Evaluating the educational impact of visualization. Paper presented at the Annual Joint Conference Integrating Technology into Computer Science Education: Working group reports from ITiCSE on Innovation and Technology in Computer Science Education. https://doi.org/10.1145/572133

[31] Nkomo, L.M., Daniel, B.K. \& Butson, R.J. (2021). Synthesis of student engagement with digital technologies: a systematic review of the literature. Int J Educ Technol High Educ, Issue 18, No. 34.

[32] Nicholson, M. \& Sanber, S. (2007). Integrating ICT into pre-service teacher education programs: Challenge and Response. Paper presented at the ISATT Conference 2007 Brock University, St. Catherines, Canada.

[33] Nor Azilah Ngah \& Mona Masood. (2006). Development of ICT Instructional Materials Based on Needs Identified by Malaysia Secondary School Teachers. Paper presented at the Informing Science and IT Education Joint Conference, Salford, UK. https://doi.org/ $10.28945 / 3008$

[34] Ozverir, I., Ulker, V. O. \& Herrington, J. (2017). Investigating the Effects of Authentic Activities on Foreign Language Learning: A Design-based Research Approach. Journal of Educational Technology \& Society, Vol. 20, No. 4, pp. 261-74.

[35] Randhawa, B. S. \& Coffman, W. E. (1978). Visual Learning, Thinking and Communication. London, United Kingdom: Academic Press Inc.

[36] Ratheeswari, K. (2018). Information Communication Technology in Education. Journal of Applied and Advanced Research, 3(S1): 45.

[37] Sapti, W., Qohar, A., Darmawan Satyananda, Atan, N. A. (2021). The Effect of Online Project-Based Learning Application on Mathematics Students' Visual Thinking Continuum in Covid-19 Pandemic. International Journal of Interactive Mobile Technologies, Vol. 15, No. 8. https://doi.org/10.3991/ijim.v15i08.21565

[38] Simpson, J. (2016). Authentic learning - Does it improve pass rates and student satisfaction? Journal of Perspectives in Applied Academic Practice, 4(2), pp. 62-70. https://doi.org/ 10.14297/jpaap.v4i2.172

[39] Tyler, D., Fore, G. A., Gabriel M. Filippelli \& Hess, J. L. (2020). A Systematic Review of The Literature on Situated Learning in The Geosciences: Beyond the Classroom. International Journal of Science Education, Vol. 42, Issue 5, pp. 722-743. https://doi.org/10. $\underline{1080 / 09500693.2020 .1727060}$ 
Paper-Students' Performance and Perceptions Towards Authentic Learning Environment Based on...

[40] Therese I. Poirier, Kate Newman \& Katie Ronald (2020). An Exploratory Study Using Visual Thinking Strategies to Improve Undergraduate Students' Observational Skills. American Journal of Pharmaceutical Education, 84(4), 7600. https://doi.org/10.5688/ajpe7600

[41] Theelen, H., Van den Beemt, A. \& Den Brok, P. (2020). Enhancing Authentic Learning Experiences In Teacher Education Through 360-Degree Videos And Theoretical Lectures: Reducing Preservice Teachers' Anxiety. European Journal of Teacher Education. https://doi.org/10.1080/02619768.2020.1827392

[42] Welzl, M., et al. (2006). Network Simulation By Mouse (NSBM): A GUI Approach for Teaching Computer Networks with the ns-2 Simulator. Paper presented at the International Conference on Interactive Computer Aided Learning (ICL 2006), Villach, Austria.

[43] White, C. M. (2001 ${ }^{\text {a }}$. Visualization Tools to Support Data Communications and Computer Network Courses. The Journal of Computing in Small Colleges, Vol. 17, No. 1.

[44] White, C. M. (2001). Creating Visualization Modules For A Data Communications And Computer Networks Course Using Low-Fidelity Prototyping. The Journal of Computing in Small Colleges, Vol.17, No.2.

[45] Wileman, R. E. (1993). Visual communicating: Englewood Cliffs, N.J.: Educational Technology Publications.

[46] Woo, Y., Herrington, J., Agostinho, S. \& Reeves, T. (2007). Implementing Authentic Tasks in Web-Based Learning Environments. EDUCAUSE Quarterly: The IT Practitioner's Journal, Vol. 30, No. 3.

[47] Yashoda, R. \& Kalpana, S. (2020). The Use of ICT Physical Education in the Partnership Teacher Training of School and Institutions. International Journal of Advanced Science and Technology, Vol. 29, No. 2, pp. 2935-2942.

[48] Yehezkel, et al. (2004). Inside the Computer: Visualization and Mental Models. Paper presented at the Third Program Visualization Workshop. The University of Warwick, UK.

[49] Yehezkel (2002). A taxonomy: Visualization of computer architecture. Paper presented at the Proc. 7th Annual Conf. on Innovation and Technology in Computer Science Education - ITiCSE 2002, Aarhus, Denmark. https://doi.org/10.1145/544414.544447

\section{Authors}

Noor Azean Atan, Associate Professor in Faculty of Social Sciences and Humanities, Universiti Teknologi Malaysia (UTM). PhD in Educational Technology from the Faculty of Education, UTM. Master in Science (Information Technology) from the Universiti Teknologi MARA and degree in Computer Science from the Faculty of Computer Science and Information Technology, UTM.

Zaidatun Tasir, Professor in Educational Technology and Dean of Faculty of Social Sciences \& Humanities, Universiti Teknologi Malaysia.

Mohd Fadzli Ali, Senior lecturer in Faculty of Social Sciences and Humanities, Universiti Teknologi Malaysia (UTM).

Mohd Shafie Rosli, Senior lecturer in Faculty of Social Sciences and Humanities, Universiti Teknologi Malaysia (UTM).

Mohd Nihra Haruzan Mohamad Said, Associate Professor in Faculty of Social Sciences and Humanities, Universiti Teknologi Malaysia (UTM).

Article submitted 2021-09-25. Resubmitted 2021-10-21. Final acceptance 2021-10-22. Final version published as submitted by the authors. 